invited to submit bids to its governing body. Cyprus, Egypt and the Palestinian Authority have indicated that they will do so, and their bids are being taken seriously. Other potential hosts, such as Turkey, may emerge after the meeting.

Despite being the Middle East's most developed country scientifically, Israel appears to have decided not to bid. This is largely because an Israel-based facility would end any hope of participation from scientists from most of the region's other countries.

"The advantages of having it in an Arab country are greater than having it in Israel," says Eliezer Rabinovici, professor of physics at the Hebrew University of Jerusalem. Scientists from Iran, Lebanon and Syria would not have been allowed by their governments to participate if there had been a chance that the facility would find a home in Israel.

But Israel's active participation is considered to be important for the project's success, says Voss.

The Palestinian Authority is a strong contender to host the synchrotron. The project's founders, together with Ernst Weihreter, a senior scientist at BESSY, have made visits to Cyprus, Israel, Jordan and the West Bank. The West Bank's chief advantages include its accessibility to scientists from both Israel and the rest of the Middle East, and a centre of scientific excellence would give a muchneeded boost to Palestinian scientists, if not the Israeli-Palestinian peace process.

"Our scientific growth has been stunted for many years, and we need opportunities to help build our infrastructure so that we can join the modern world," says Hanna Hallak, dean of science and chairman of the physics department at Bethlehem University.

But a Palestinian bid has two prerequisites, which may not be easy to obtain. The first is continued peace between the government of Israel and its Palestinian population - renewed unrest will make it difficult for scientists from other countries to work at the centre. A second prerequisite is that most of the funding will need to be found overseas, as the Palestinian Authority is unlikely to contribute substantially to the facility.

This is where the supporters of Egypt's bid believe that they could have an edge. Egypt remains more stable politically than its neighbour. The government is also prepared to invest considerable sums towards the facility's construction and running costs, says Hamid Roushdy El-Kady, emeritus professor of radiation biology at the National Centre for Radiation Research and former chairman of Egypt's Atomic Energy Authority.

Egypt has been developing accelerator technology since 1961, says El-Kady, adding that most of the region's non-Israeli scientists go to Egypt for training in radiation biology and high-energy physics. EhsanMasood

\title{
Biotech panel set up in US may help allay public fears
}

[WASHINGTON] The US Department of Agriculture (USDA) is to set up a biotechnology advisory committee made up of scientists, farmers, industry groups, environmentalists and members of the public. The move has been made partly in the hope that it may head off the kind of controversy over genetically modified (GM) foods that has raged recently in Europe.

The department plans to begin soliciting nominations for members this week. The agriculture secretary, Dan Glickman, who announced the new committee in March, will select 25 people representing a range of viewpoints. According to Michael Schechtman of the USDA, who will be the panel's executive secretary, the committee will be expected to meet a maximum of four times a year.

Environmentalists have praised USDA's new willingness to listen to public concern about agricultural biotechnology. While cautioning that the committee's goals are "still a little unclear", Rebecca Goldburg of the Environmental Defense Fund in New York says that it represents "a real change".

"I think Glickman has been gaining an understanding that he and industry cannot talk this problem away," says Jane Rissler of the Union of Concerned Scientists. USDA, along with the Environmental Protection Agency (EPA) and the Food and Drug Administration, has regulatory responsibility for GM foods.

Glickman appears to have backed away recently from what some have characterized as unabashed 'boosterism' about GM crops. "We can't force these new genetically engineered food products down consumers' throats," he said in April at a commencement ceremony at Purdue University, Indiana. "Dismissing the scepticism that's out there is not only arrogant, it's also a bad business strategy," he added.

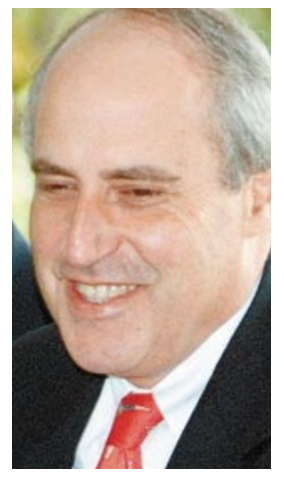

Glickman: 'let's win over our opponents'.
Regarding the decision by some British supermarket chains to ban GM foods, the secretary said that such organizations needed "a little bit of educating, but I don't think we can just sit here and berate them".

He struck a similar tone before the World Agricultural Congress in St Louis in May, saying: "Americans are more willing to see science as a force for progress... while Europeans may be more cautious, more concerned perhaps about even the theoretical possibility of risk."

But the USDA panel's membership may be contentious, if a recent fight over the composition of a National Academy of Sciences committee on pesticide-resistant GM plants is an indication of how polarized the debate has become (see Nature 399, 7; 1999).

Attempts to bring all the 'stakeholders' around the same table can backfire badly, as in the case of a 50-member panel formed by the EPA, at the request of the vice-president, Al Gore, to discuss pesticides in food. In April, seven environmental groups walked out of the Tolerance Reassessment Advisory Committee, claiming that it was dominated by agricultural and chemical interests.

The EPA is holding public meetings this summer to discuss pest-resistance management plans for GM crops.

But there has been little progress on a proposal to raise GM crops as a trade issue at a meeting of G8 nations this summer, which some in Congress have been pushing (Nature399, 287; 1999).

Tony Reichhardt

\section{German plan to curb rise in research funds}

[MUNICH] Germany's 16 Länder (states) say they want to cut down considerably on the five per cent increase in next year's budget that has been promised to the main basic research organizations, the Deutsche Forschungsgemeinschaft (DFG) and the Max Planck Society (MPS).

The DFG and MPS are jointly funded by the federal government and the Länder. A recent report from the German Press Agency quotes an unpublished agreement drawn up by the Länder ministers of finance to limit the budget increase to two per cent in 2000 . The agreement also says that budgets should be negotiated annually in future, rather than guaranteeing fixed mid-term increases.

If approved by the Länder this month, the plan could hinder implementation of the recommendations of an external committee that evaluated internal procedures of the MPS and DFG (see Nature 399, 395-396; 1999). The committee said that a guaranteed mid-term financial framework should be maintained to allow reforms to be made. But the federal government is unlikely to block a cost-cutting Länder agreement at a time when the federal budgets for 2000 are to be reduced by 7.4 per cent. Quirin Schiermeier 